\title{
STUDIES OF NON-MARINE MOLLUSKS FOR THE SELECTION OF SHELL SAMPLES FOR RADIOCARBON DATING
}

\author{
TIMOTHY YATES
}

Department of Geography, University College London, Bedford Way London WC1H OAP, England

\begin{abstract}
C}$ dating of shells from terrestrial and freshwater mollusks is prone to distortion by post-depositional diagenesis as well as incorporation of material depleted in ${ }^{14} \mathrm{C}$, while the mollusk was alive. Three types of diagenetic change can result: etching, the development of surface crusts, and replacement of aragonite by calcite. Inspection under the light microscope, $x$-ray diffraction, and scanning electron microscope make it possible to assess the relative importance of the changes. When they are confined to the surface, mechanical cleaning combined with judicious leaching can reduce them to $<1 \%$ of the total sample. The corresponding errors, which can now be specified, are often no greater than those associated with the statistics of counting.
\end{abstract}

\section{INTRODUCTION}

The chronology of paleo-environmental development often calls for ${ }^{14} \mathrm{C}$ dating of some form of calcium carbonate, such as shells, carbonate nodules, calcite, or tufa. Although these materials may be available in quantities that allow conventional ${ }^{14} \mathrm{C}$ dating (Evin et al, 1980); Thorpe, Otlet \& Sweeting, 1980; Callen, Wasson \& (Gillespic, 1983), and will certainly be available in the quantities required for AMS techniques, they are often used only as a last resort because the ages they yicld are viewed with skepticism.

Earlier studies on marine mollusks (Cillespie \& Polach, 1979; Mangerud, 1972) have suggested that the associated errors may be quantifiable within statistical limits, and the work of Vita-Finzi (1980) and Vita-Finzi and Roberts (1984) has emphasized the importance of sample preparation in obtaining reliable results. Olsson, Goksu and Stenberg (1968) have also emphasized the risk for contamination by adsorption of $\mathrm{CO}_{2}$ by storing in the atmosphere. Land and freshwater molluscan shells are even more suspect than marine shells since they contain material that may have been severely depleted in ${ }^{14} \mathrm{C}$ when taken from the environment, besides being subject to recrystallization and contamination since death. This paper shows that, once the original shell structure has been recognized, diagenetic change can readily be identified using the SEM and often the light microscope. It goes on to show how this major source of error can be eliminated or, failing that, quantified so that suitable error values can be set on the age.

\section{METHODS AND TECHNIQUES}

In order to make a reliable assessment of the extent and position of diagenetic changes and areas of contamination it was necessary to establish the form of unaltered structures, the levels at which diagenetic material and contamination could be detected, and their potential for removal. The techniques necessary to achieve these aims were integrated to give a consistent and reliable method. 


\section{Cleaning}

All external shell surfaces were cleaned in distilled water and then sectioned parallel to the columella using a Black and Decker Minicraft drill fitted with a cutting disk $1 \mathrm{~mm}$ thick. When used at the correct speed for a particular shell thickness sectioning of samples $<0.5 \mathrm{~mm}$ thick was readily achieved. The columella was discarded as its narrow cylindrical form is difficult to clean. The samples were then placed in an ultrasonic cleaner filled with distilled water for 10 minutes and then examined under a low-power binocular microscope for any adhering particles. If the particles remained cemented to the shell, mechanical cleaning using diamond drills and grinding wheels was undertaken before further ultrasonic cleaning.

\section{Mineralogy}

Analysis of modern samples confirmed that all the species studied were pure aragonite unless they contained regenerated shell material (Saleuddin, 1971). Each shell was then sampled at five points to provide a $50 \mathrm{mg}$ sample for XRD analysis. The sample was ground to ca $10 \mu$ and the powder placed onto a glass slide in an acetone slurry. The analyses were undertaken on a Philips PW 1010 diffractometer with a $\mathrm{CuK}_{\alpha}$ source fitted with a Ni filter. The scan speed was $1 \%$ min and calibration showed the minimum detectable limit to be $0.6 \%$ calcite.

\section{Microscopic Analysis}

All samples containing calcite and a number of pure aragonite were examined under a scanning electron microscope. Acetate peels were produced for the thicker shelled species only because experiment suggested a minimum shell thickness of $0.5 \mathrm{~mm}$ was required for this technique to succeed.

Samples for the SEM were coated with gold/palladium and examined using a Jeol $35 \mathrm{CF}$ and an Hitachi S-530, both operating at $25 \mathrm{KV}$. The working range was 30-30,000 times, so that single aragonite crystal units could be resolved.

If observation showed the contamination or recrystallization to be a surface deposit, further cleaning was undertaken followed by further XRD analysis. When the shell was judged to be clear of calcite, the whole shell was etched in $5 \% \mathrm{HCl}$, rinsed in distilled water, dried, and ground. The sample was then subsampled and again analyzed for calcite. Samples in which none was detected were considered suitable for ${ }^{14} \mathrm{C}$ analysis.

The use of stable isotopes $\left({ }^{13} \mathrm{C} /{ }^{12} \mathrm{C},{ }^{18} \mathrm{O} /{ }^{16} \mathrm{O}\right)$ for detecting diagenetic change was also considered. Gavish and Friedman (1969) showed a correlation between percentage recrystallization and stable isotope ratio for marine deposits. However, the wide variation in these values for nonmarine shells and the similarity of the initial and recrystallized values precludes their use for all but the most severely affected shells.

\section{STRUCTURES PRESENT IN FRESHWATER AND TERRESTRIAL SHELLS}

Details of the structures of 18 freshwater bivalves were already available (Taylor, Kennedy and Hall, 1969; Mackie, 1978) and the observations 
on Unio species were confirmed by further study. Eight species of freshwater and 15 species of terrestrial gastropods were examined, the structure of only one species being known from earlier research. The nomenclature used is based on that of Taylor, Kennedy and Hall (1969).

Five structures were found to be present: crossed-lamellar, complex crossed-lamellar, sheet nacreous, lenticular nacreous, and prismatic, the last four being present only in the freshwater bivalves.

\section{Sheet Nacreous Structure}

This is distinguished by the regular arrangement of layers parallel to the shell interior. The overall effect is of a brick wall, with the interlamellar and intercrystalline organic matrices representing the mortar.

\section{Lenticular Nacreous Structure}

In this form the euhedral or rounded tablets, formed of piles of thin layers, are stacked in uneven groups. In general, the surfaces are distorted, leading to a more irregular form than that of sheet nacre.

\section{Prismatic Structure}

The prisms that form the basic structural unit are generally pentagonal cells divided from one another by thick conchiolin walls. The cells are narrow near the periostracum, giving rise to a large number of small prisms. Geometric selection eliminates many of these in growth and the characteristic prismatic form is produced.

\section{Crossed-Lamellar Structure}

This is the only structure found in non-marine gastropods, though its exact form shows wide variation. The structure is formed from a three-fold hierarchy consisting of first-, second-, and third-order lamellae (Pl 1). MacClintock (1967) and Phillipon (1974) describe two types of crossed-lamellar structure, concentric and radial, that differ in their orientation to the shell margin. Both types occur in most gastropod shells.

\section{Complex Crossed-Lamellar Structure}

This form is built of the same structural units as the crossed-lamellar structure but with four orientations of crystallites instead of two.

\section{DIAGENETIC STRUCTURES}

The present study of fossil shells ( $3000-9000 \mathrm{BP})$ from the British Isles revealed three forms of post-depositional changes: surface etching, formation of surface crusts, and recrystallization. Associated with these is the exfoliation of shell layers.

After burial, the shells may undergo changes. The first is the loss of the periostracum, allowing ground waters access to the crystal structure. The terrestrial gastropods, with the exception of Pomatias elegans, are formed from 2 or 4 layers of crossed-lamellar structure. These layers begin to part after a short time, possibly before burial is complete. This is probably because layers of different crystal orientation suffer differential expansion 
Plate 1

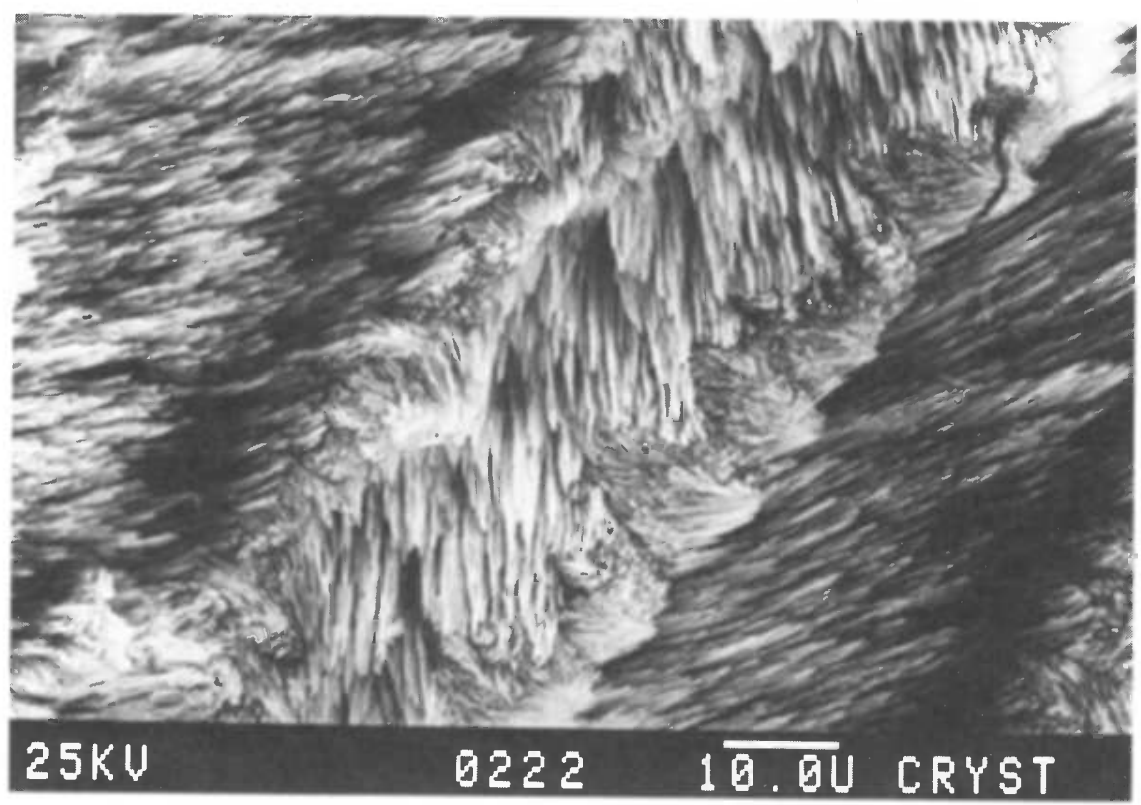

Unaltered structure (crossed-lamellar) in the shell of Theodoxus fluviatilis

Plate 2

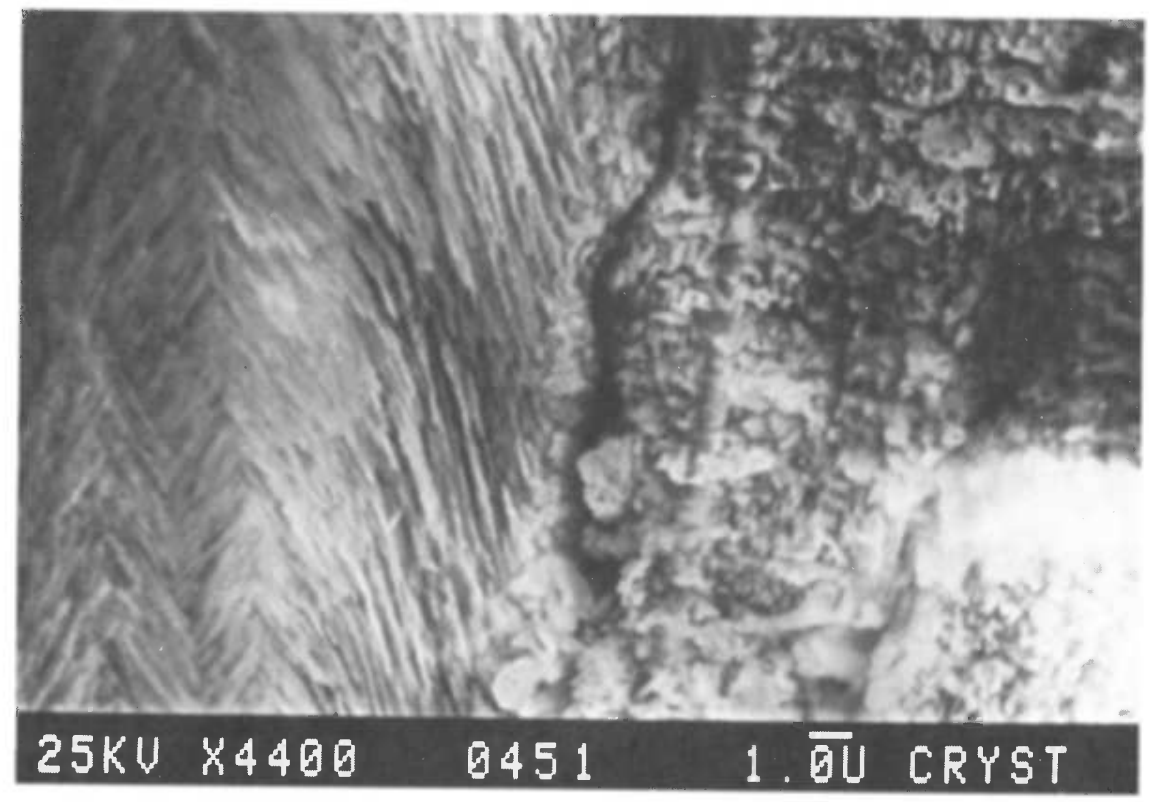

Exfoliation of recrystallized material (right) from the unaltered crossed-lamellar structure (left) (Cepaea nemoralis, $7880 \pm 160 \mathrm{BP}$ ) 
when subjected to changes in temperature and moisture. The process is a form of exfoliation and accounts for the "flakey" texture frequently found in non-marine gastropod shells. The gaps caused by exfoliation are susceptible to both contamination and the growth of secondary calcite.

\section{Etching}

This appears to represent the earliest stages of dissolution. Alexandersson (1978) and Walker (1979) observed this effect at up to $300 \mu$ from the surface. However, in the terrestrial gastropods examined the attack was confined to the surface and had penetrated only a few microns perhaps because each of the third-order lamellae in the structure was protected by organic matrix. The surfaces available for dissolution are increased by the exfoliation processes because it gives access to the first-order lamellae interfaces which are not protected by organic matrices.

\section{Surface Crusts}

This form of diagenetic change was observed on many shells. A similar structure was recorded by Evans (1972), who suggested it was a secondary deposit on the original shell surface. The present study suggests that it can also be formed by recrystallization of original shell material. It was observed on both inner and outer surfaces, but only occasionally exceeded $10 \mu$ in thickness. The thickness is limited by the crust breaking away from the shell surface, as was clearly seen in a number of specimens. This is also seen as exfoliation and is comparable with the loss of the hydration layers observed on obsidian. The exfoliation of crusts may owe something to differential expansion of the shell aragonite relative to the calcite crust.

\section{Replacement of Aragonite by Calcite}

Where the surface crusts had not peeled off, or where the recrystallization had taken place from an inner layer surface, larger areas of replacement calcite where found (Pl 2). In the shells studied, this did not form a major part of the shell, the highest level being ca $5 \%$. However, this still represents an unacceptably high level in older samples.

The recrystallization process appears to conform to the model proposed by Pingitore $(1976 ; 1982)$, with a narrow diagenetic front separating the calcite from the unaltered aragonite. However, although the front is narrow $(1-2 \mu)$ no apparent retention of the original structure was observed.

\section{THE EFFECT OF DIAGENETIC CHANGES ON ${ }^{14} \mathrm{C}$ DATES}

The diagenetic deposits detected all affected $<5 \%$ of the total sample volume. Surface etching will cause no error in the ${ }^{14} \mathrm{C}$ date, but can be taken as evidence of an environment in which dissolution and therefore recrystallization may be taking place.

The formation of a surface crust will involve the incorporation of material with a different ${ }^{14} \mathrm{C}$ value from that of the sample, and therefore, an age error. However, the position of the deposit allows it to be removed mechanically from the shell surface. Replacement calcite can also be 
removed if accessible, but if it is within the shell, this part of the shell must be discarded.

If the diagenetic products are submitted as part of the sample, a 5\% level of modern pre-bomb contamination could produce errors of ca 1000 years on a 10,000 BP sample, and ca 17,000 years on a 40,000 BP sample. Thus, it is essential that the most rigorous steps be taken to clean shell material, as the apparent age due to environmental contributions during the life of the mollusk (500-2500 yr) can easily be overshadowed by the diagenetic and contamination errors.

\section{CONCLUSION}

The work so far completed in this project has shown that one of the two major problems associated with the use of non-marine shells for ${ }^{14} \mathrm{C}$ dating can be reduced to low levels and in the case of younger samples confined to within the statistical errors associated with counting. To achieve this requires a rigorous approach to the cleaning and preparation of material for dating. The methods described here are simple and rely on equipment that is readily available.

Work in progress deals with the second main source of error, namely, the uptake of material deficient in ${ }^{14} \mathrm{C}$, and again seeks to facilitate the selection of samples in the field and to evaluate the probable size of the error, this time by isotopic analysis of the environment occupied by the mollusk. The results obtained so far reinforce the view that with careful selection and pretreatment non-marine shells can be suitable material for ${ }^{14} \mathrm{C}$ dating.

\section{ACKNOWLEDGMENTS}

I should like to thank C Vita-Finzi, Department of Crystallography, Birkbeck College, and the Department of Geology, University College London, for help and advice. The work is funded by the NERC.

\section{REFERENCES}

Alexandersson, E T, 1978, Destructive diagenesis of carbonate sediments in the eastern Skagerrak, North Sea: Geology, v 6, p 324-327.

Callen, R A, Wasson, R J and Gillespie, R, 1983, Reliability of radiocarbon dating of pedogenic carbonate in the Australian arid zone: Sed Geol, v 35, p 1-14.

Evans, J G, 1972, Land snails in archaeology: London and New York, Seminar Press.

Evin, J, Marechal, J, Pachiaudi, C and Puissegur, J J, 1980, Conditions involved in dating terrestrial shells, in Stuiver, $\mathrm{M}$ and $\mathrm{Kra}, \mathrm{R} \mathrm{S}$, eds, Internatl ${ }^{14} \mathrm{C}$ conf, 10th, Proc: Radiocarbon, v 22, no. 2, p 545-555.

Gavish, E and Friedman, G M, 1969, Progressive diagenesis in Quaternary to Late Tertiary carbonate sediments: Sequence and time scale: Jour Sed Petrol, v 39, no. 3, p 9801006 .

Gillespie, R and Polach, H A, 1979, The suitability of marine shells for radiocarbon dating of Australian prehistory, in Berger, $\mathrm{R}$ and Suess, $\mathrm{H} \mathrm{E}$, eds, Radiocarbon dating, Internatl ${ }^{14} \mathrm{C}$ conf, 9 th, Proc: Berkeley, Univ California Press, $\mathrm{p} 404-421$.

MacClintock, C, 1967, Shell structures of patelloid and bellerophontoid gastropods (Mollusca): Peabody Mus Nat Hist Bull, v 22, p 1-140.

Mackie, G L, 1978, Electron microscopy of Pisodiiae: Can Jour Zool, v 56, no. 1, p 1-6.

Mangerud, J, 1972, Radiocarbon dating of marine shells, including a discussion of apparent age of Recent shells from Norway: Boreas, v 1, no. 2, p 143-172.

Olsson, I U, Göksu, Y and Stenberg, A, 1968, Further investigations of storing and treatment of Foraminifera and mollusks for ${ }^{14} \mathrm{C}$ dating: Geol Fören Stockholm Förh, v 90, p 417 426. 
Phillipon, J, 1974, Structure et composition mineralogique de la coquille de Gastropodes actuels et fossiles: Notes Contr Cent Etudies Recherche Paleontol Biostrat, v 7, p 1-84.

Pingitore, N E, 1976, Vadose and Phreatic diagenesis: Processes, products and their recognition in corals: Jour Sed Petrol, v 46 p 985-1006. $27-39$

1982, The role of diffusion during carbonate diagenesis: Jour Sed Petrol, v 52, p

Saleuddin, A S M, 1971, Fine structures of normal and regenerated shell of Helix: Can Jour Zool, v 49, p 37-41.

Taylor, J D, Kennedy, W J and Hall, A, 1969, The shell structure and mineralogy of the Bivalvia. I. Introduction. Nuculacea-Trigonacea: Bull British Mus (Nat Hist) Zool, Supp 3, p 1-125.

Thorpe, P M, Otlet, R L and Sweeting, M M, 1980, Hydrological implications from ${ }^{14} \mathrm{C}$ profiling of UK tufa, in Stuiver, M and Kra, R S, eds, Internatl ${ }^{14} \mathrm{C}$ conf, 10 th, Proc: Radiocarbon, v 22, no. 3, p 897-908.

Vita-Finzi, C, 1980, ${ }^{i 4} \mathrm{C}$ dating of recent crustal movements in the Persian Gulf and Iranian Makran, in Stuiver, M and Kra, R S, eds, Internatl ${ }^{14} \mathrm{C}$ conf, 10th, Proc: Radiocarbon, $v$ 22, no. 3, p 763-773.

Vita-Finzi, C and Roberts, N, 1984, Selective leaching of shells for ${ }^{14} \mathrm{C}$ dating: Radiocarbon, $v$ 26 , no. 1, p $54-58$

Walker, B M, 1979, Shell dissolution: Destructive diagenesis in a meteoric environment: Scanning Electron Microscopy, no. 2, p 463-468. 